Katarzyna ŚwierczewsKa-Pietras

Kraków

\title{
Rewitalizacja zamknięta jako przykład zagospodarowania poprzemysłowego obszaru Lodzi
}

Celem artykułu jest opis i analiza pojęcia rewitalizacji zamkniętej jako przykładu zmiany funkcji poprzemysłowego obszaru fabryki I.K Poznańskiego w Łodzi.

W Polsce, z uwagi na transformację ustrojową, gospodarczą, przystąpienie do Wspólnoty Europejskiej, a obecnie wyrównywanie szans i dzielącego nas dystansu do krajów Europy Zachodniej, coraz częściej przywiązuje się wagę do rewitalizacji zdegradowanych obszarów przestrzeni miejskiej. W ostatnich latach przystapiono do realizacji kilku projektów rewitalizacyjnych zmieniających funkcje terenów poprzemysłowych. Nierentowna działalność zakładów doprowadzała do spadku produkcji, a tym samym zatrudnienia. Kubatura obiektów przemysłowych i techniczne trudności często nie pozwalały na ich zagospodarowanie przez potencjalnych najemców. Przez wiele lat nieużytkowane, traciły walory architektoniczne, pogłębiając degradację przestrzenną obszaru. Tym samym zatracała się tożsamość miast związanych z produkcją przemysłową. Szansą na ich zagospodarowanie oraz rozwój otoczenia była zmiana funkcji poprzez rewitalizację.

\section{Proces Rewitalizacji}

Pojęcie rewitalizacji związane jest z odnową zdegradowanych obszarów miast, często poprzemysłowych, i ponownego włączenia ich w proces rozwoju przestrzenno-funkcjonalnego w miejskich strukturach miasta. Słowo rewitalizacja pochodzi od języka łacińskiego re-vita, czyli przywrócenie do życia, ożywienie. W literaturze można spotkać thumaczenie pojęcia rewitalizacji jako „kompleksowego procesu odnowy obszaru zurbanizowanego, którego przestrzeń, funkcje i substancja uległy procesowi strukturalnej degradacji, wywołującej stan kryzysowy, uniemożliwiający lub znacznie utrudniający prawidłowy rozwój ekonomiczny i społeczny tego obszaru, jak i zrównoważony rozwój całego miasta”.

Rewitalizacja jest pojęciem nadrzędnym w stosunku do pojęć takich jak: rehabilitacja, rewaloryzacja, przebudowa, restrukturyzacja, modernizacja, regeneracja, konserwacja, rekultywacja, sanacja, remont itp. Łączy w sobie elementy planowania przestrzennego, rozwoju gospodarczego i społecznego, ochrony środowiska naturalnego i dziedzictwa kulturowego. Do działań rewitalizacyjnych zaliczyć należy odbudowę lub przebudowę aktywnych w przeszłości obszarów miejskich (np. centrów starych miast), mocno zdekapitalizowanych 
lub nawet zniszczonych w wyniku działań wojennych lub też powojennych dewastacji i rozbiórek. Ich odbudowa/przebudowa służy zarówno rewitalizacji tych terenów, jak i całego miasta. Rewitalizacja wymaga kompleksowego ujęcia wielu różnorodnych dziedzin, składających się na funkcjonowanie organizmu miejskiego. Są to m.in. sfery: społeczna, ekonomiczna, ekologiczna, prawna, finansowa i planistyczno-przestrzenna. Rewitalizacja - odnowa miasta - to proces wielokierunkowy, rozłożony w czasie. Jego horyzont zwykle obejmuje dziesięć do piętnastu lat, a w szczególnych znanych przypadkach - nawet więcej.

\section{REWITALIZACJA ZAMKNIĘTA A EFEKT SPILL-OVER}

Pozytywne aspekty rewitalizacji terenów zdegradowanych wpływają nie tylko na ich rozwój, ale służą miastu, gdyż generują przemiany okolicznych obszarów. Najistotniejszym czynnikiem rewitalizacji jest wywoływanie efektu spill-over, tzw. rozlewania czy rozprzestrzeniania się na obszary przyległe. To zjawisko można nazwać rewitalizacją otwartą, tzw. na zewnątrz, która poprzez swoje działania przenosi się na obszary sąsiadujące. Wpływa na zmianę ich funkcji, rozwój zdegradowanej infrastruktury, poziom bezpieczeństwa mieszkańców i ich zadowolenie z podniesienia standardu życia. Rewitalizacja pojmowana w taki sposób jest stymulatorem zmian obszaru poprzez wpływ na poziom bezrobocia mieszkańców, ubóstwa oraz trudnych warunków mieszkaniowych, przestępczości, wykształcenia mieszkańców i ich przedsiębiorczości, degradacji technicznej infrastruktury i budynków, zanieczyszczenia środowiska naturalnego.

Zmiany na rewitalizowanym obszarze, które nie przenoszą się na obszary sąsiadujące, możemy nazwać rewitalizacją zamkniętą, tzw. do wewnątrz, skupiającą się tylko w granicach obszaru przeznaczonego do rewitalizacji, nie wpływającą na kondycję obszarów przyległych, również będących w stanie kryzysu. W tym przypadku nie dochodzi do efektu spill-over. Rewitalizacja ujmowana w taki sposób nie przyczynia się do pozytywnego przenoszenia dobrych praktyk na tereny sąsiadujące. Można uznać, iż jest to rewitalizacja, która poprzez swoje działanie nie dała dobrego impulsu do zmian na obszarach przyległych. Przykładem rewitalizacji zamkniętej w zagospodarowaniu obszaru jest fabryka I.K. Poznańskiego w Łodzi, którą zaadaptowano na centrum kulturalno-rozrywkowo-handlowe Manufaktura.

\section{PoprZEMYSŁOWY CHARAKTER MIASTA}

Łódź to miasto posiadające jedne z najcenniejszych zespołów architektury fabrycznej w Polsce. Ich początki sięgają lat 20. XIX w., kiedy władze autonomicznego Królestwa Polskiego podjęły program modernizacji kraju. W 1820 r. włączono Łódź do osad poprzemysłowych i postanowiono uczynić kolebką polskiego włókiennictwa. Dzięki wielu ułatwieniom w zakładaniu przedsiębiorstw, jak m.in. zwolnieniu od służby wojskowej w zamian za pracę we włókiennictwie, do Łodzi zaczęli przybywać fabrykanci z całego świata. Pierwszym budynkiem przemysłowym z prawdziwego zdarzenia był bielnik. W 1835 r. powstała pierwsza łódzka fabryka z tkalnią i kominem, zwiastującym technologiczny postęp miasta. 
Klasa łódzkich przedsiębiorców świadoma swoich ekonomicznych interesów i relacji społeczno-politycznych ukształtowała się do lat 60. XIX w. (Missalowa 1977, s. 165). W Łodzi działało wówczas ok. 800 fabryk, m.in. fabryka wyrobów bawełnianych i gumowych Ferdynanda Goeldnera (powstała ok. 1883 r.), przędzalnia bawełny Markusa Silbersteina (1892 r.), fabryka wyrobów bawełnianych Szai Rosenblatta (ok. 1890 r.), najbardziej znana fabryka wyrobów bawełnianych Izraela K. Poznańskiego (1892 r.), fabryka wyrobów bawełnianych Karola Scheiblera (1872 r.) czy fabryka wyrobów bawełnianych Ludwika Geyera. Przedsiębiorcy ci uczynili ze swoich fabryk świetnie prosperujące przedsiębiorstwa, w których pracowało do 6 tys. robotników, a po połączeniu fabryk Grohmana i Scheiblera w Zjednoczone Zakłady K. Scheiblera i L. Grohmana S.A. zatrudnionych było aż 8 tys. pracowników. Większość łódzkich potęg włókienniczych przetrwała do II wojny światowej, aby później już nigdy nie powrócić do lat świetności. Po wojnie niektóre z nich czekały na inwestorów, inne w przy braku zagospodarowania popadły w ruinę, a wraz nimi zabytkowa fabryczna architektura. W latach 90. fabryczne zabudowania stanowiły jeden z najpoważniejszych problemów w funkcjonowaniu miasta, które nie miało funduszy na ich zagospodarowanie. Obecnie z uwagi na trend w zmianie funkcji obszarów poprzemysłowych realizowane są jedne z największych projektów rewitalizacyjnych nie tylko w Polsce, ale również na świecie.

\section{HISTORIA FABRYKI}

Fabryka Izraela Poznańskiego powstała w latach 70. XIX w. na powierzchni 12 ha, otoczonej ulicami: Ogrodową, Zachodnią, Drewnowską oraz Srebrzyńską. Ulica Ogrodowa pełniła wówczas strategiczną rolę w komunikacji dzielnicy. Łączyła ona w linii prostej produkcyjne serce przedsiębiorstwa - tkalnię i przędzalnię - z ulica zachodnią i traktem piotrkowskim. Jednocześnie nawiązywała do drogi polnej w kierunku cmentarza, dzieląc grunty miejskie od „ziem Poznańskiego”. Dzięki takiemu układowi pełniła funkcję naturalnej granicy miasta i rewiru żydowskiego, tworząc tym samym ,dzielnicę przemysłową” na przedmieściu Nowego Miasta (Szram 1998, s. 53). Budowę kompleksu przemysłowego z zagospodarowaniem terenu Poznański powierzył miejskiemu architektowi Hilaremu Majewskiemu. Za datę wzniesienia pierwszych budowli przyjmowany jest rok 1872 r. (Szram 1998, s. 55). Poznański uruchomił wówczas pierwszą tkalnię wyposażoną w krosna mechaniczne napędzane maszyną parową. Przez następne dwadzieścia lat pomnażał swoje imperium budując przędzalnię, barwiarnię tkanin, magazyny bawełny, gazownię, warsztaty naprawcze, kantor, sklepy, kasę, a także z powodu licznych podpaleń fabryki, własną remizę strażacką. Izrael Poznański w rozwoju swojego przedsiębiorstwa dążył do jego funkcjonalności. Dlatego przy fabryce w latach 1879-1896 wybudował osiedle robotnicze tworzące zespół przy ulicach Ogrodowej i Gdańskiej. Według oficjalnych danych z 1900 r., fabryka posiadała trzy domy dla robotników i osiemnaście mniejszych, o łącznej liczbie 1086 mieszkań dla 4036 osób (Popławska 1992, s. 100). Aby jeszcze bardziej związać swoich pracowników z miejscem i fabryką, w 1888 r. postawił na terenie przedsiębiorstwa modrzewiowy kościół pw. św. Józefa (Szram 1888, s. 57).

Poznański dbał również o własny prestiż i wygodę. W 1888 r. Hilary Majewski zaprojektował dla fabrykanta rezydencję: dwukondygnacyjny budynek z podpiwniczeniem 
na pomieszczenie domu mieszkalnego, magazynów, pokoi gościnnych i ogrodu zimowego. W projekcie budowla rysuje się w kształt litery L i przylega dłuższym bokiem do ulicy Zachodniej mającym długość ok. 120 m, a krótszym do ul. Ogrodowej o długości ok. 24 m. Parter rezydencji przeznaczony został na cele usługowe - biura, kasę, gabinet właściciela, pomieszczenie do sprzedaży towarów z osobnym wejściem oraz magazyny. Na pierwszym piętrze przewidziano salon, pokoje dla gości i mieszkańców, a na poddaszu pomieszczenia dla służby. Nad środkową częścią pałacu na drugiej kondygnacji zlokalizowano całkowicie przeszklony ogród zimowy, nad którym unosiły się trzy szklane kopuły. Projekt ogrodu przewidywał, iż jego przestrzeń miała zajmować około $770 \mathrm{~m}^{2}$. Elewacja budynku była wzorowana na stylu renesansowym. Jednak rezydencja w tak okazałej formie nigdy nie powstała (Popławska 1992, s. 77).
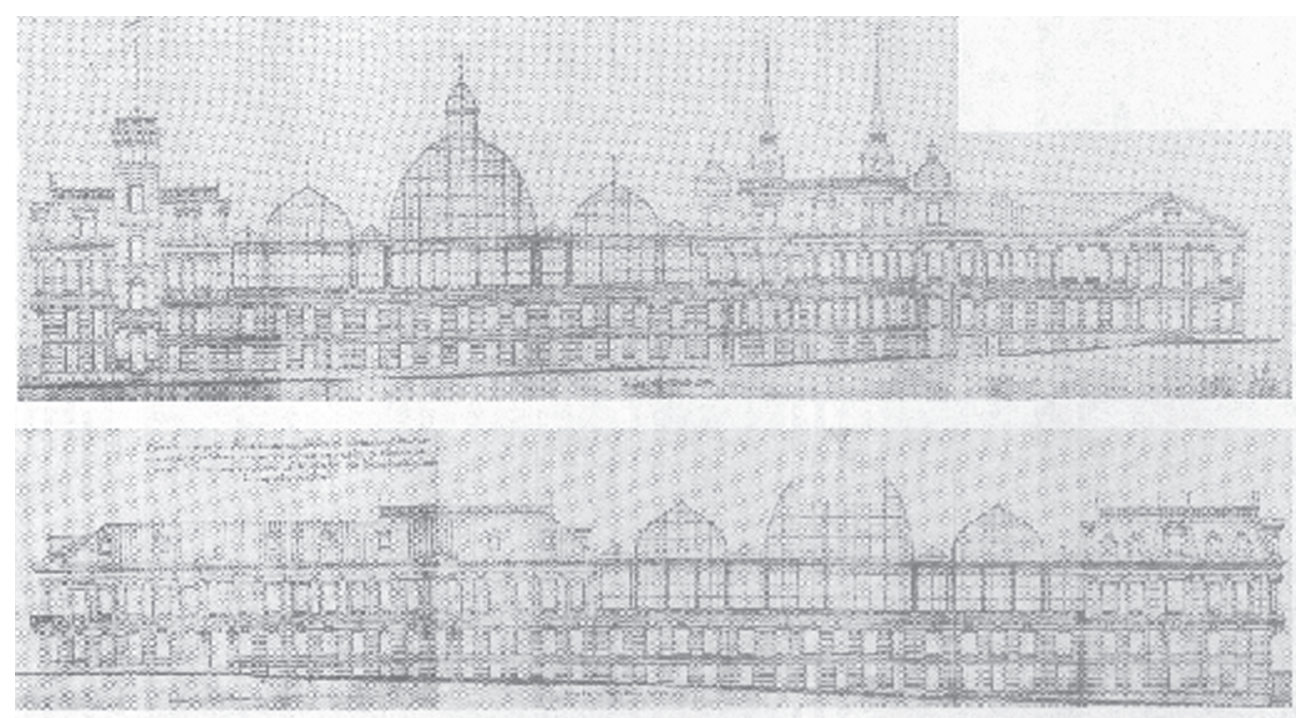

Ryc. 1. Widok elewacji pałacu pierwszego projektu z przeszklonymi kopułami ogrodu zimowego

Źródło: I. Popławska 1992, s. 79

W 1900 r. Poznański zlecił kolejny projekt pałacu nieznanemu architektowi, który zmienił wielkość budynku wzdłuż ul. Ogrodowej celem stworzenia niedużego ogrodu zimowego, zrezygnowano bowiem z koncepcji umieszczenia ogrodu na drugiej kondygnacji budowli. Projekt przewidywał także zmiany w elewacji, wprowadzał nowy element w postaci wieży w narożniku. Jednak i on nie został zrealizowany, a obecny kształt budynku powstał na bazie kolejnego projektu. Poznański nie doczekał końca rozbudowy pałacu. Jego dzieło kontynuował syn, ale obecny wygląd rezydencji jest wynikiem licznych przeróbek. Budowla została nazwana „łódzkim Luwrem”, znacznie przedłużona, w niektórych partiach podwyższona, dobudowano też nowe skrzydło. W okresie międzywojennym pałac był siedzibą urzędu wojewódzkiego. Obecnie w jego części mieści się Muzeum Historii Miasta Łodzi.

Majątek Poznańskiego czynił go najbogatszym żydowskim przedsiębiorcą w Łodzi i cesarstwie rosyjskim. Wartość inwestycji w jego przedsiębiorstwie wynosiła wówczas 
ok. 15 mln rubli rocznie, przy zatrudnieniu ok. 6 tys. pracowników. Fabrykant nie cieszył się jednak długo bogactwem, umarł w $1900 \mathrm{r}$.

Jeszcze za jego życia przedsiębiorstwo zostało w 1889 r. przekształcone w Towarzystwo Akcyjne Wyrobów Bawełnianych. W czasie I wojny światowej kondycja finansowa Towarzystwa znacznie się pogorszyła, tym samym powodując zadłużenie w bankach włosko-szwajcarkich, które w latach 30. XX w. przejęły kierownictwo nad Towarzystwem. W czasie II wojny światowej wszystkie akcje spółki przejął okupant niemiecki, za panowania którego w zakładach produkowano tkaniny dla wojska oraz podzespoły do samolotów. Po wojnie przedsiębiorstwo znacjonalizowano pod nazwą Zakłady Przemysłu Bawełnianego im. Juliana Marchlewskiego, a w 1970 r. uzupełniono branżową nazwą Poltex. W 1989 r. fabrykę postawiono w stan likwidacji. Ostatecznie produkcja została zakończona w 1997 r. Od tego czasu likwidator szukał inwestora, który byłby w stanie zrewitalizować obszar fabryki.

\section{ANALIZA OBSZARU - PROJEKT REWITALIZACYJNY}

W 1999 r. fabrykę przejęła firma Absys, by zmienić funkcję poprzemysłowego obszaru i nadać mu nowe znaczenie w strukturze miasta. Początkowo inwestycja miała się nazywać Nowy Świat Łódź, ale podczas badań przeprowadzonych w $2001 \mathrm{r}$. okazało się, że nazwa ta nie jest akceptowana przez mieszkańców. Inwestorzy pozostali przy nazwie Manufaktura. Pierwszym zaadaptowanym do nowych celów budynkiem była siedziba Straży Pożarnej. Powstało w niej Centrum Informacyjne Manufaktury. Od tego czasu organizowano liczne akcje promocyjne nastawione na odbiór jak największej liczby mieszkańców Łodzi. Inwestor starał się przedstawić projekt poprzez udział m.in. w kongresie TILE - Trends in Leisure and Entertainments w Berlinie, kongresie Urbanistów Polskich w Gdańsku, podczas konferencji zorganizowanej przez Polską Akademię Nauk, konferencji w Pradze, gdzie podczas europejskiej sesji ULI Manufaktura została przedstawiona jako przykład nowych kierunków rozwoju projektów o charakterze handlowym. Projekt był również przybliżany mieszkańcom, poprzez codzienne wycieczki pt. Wycieczki śladami I. Poznańskiego w fabryce. Budowę rozpoczęto w maju 2003 r. Jej bilans wygląda następująco:

Tab. 1. Bilans prac budowlanych

\begin{tabular}{|l|l|}
\hline 1. Wyremontowano & $270000 \mathrm{~m}^{2}$ terenu \\
\hline 2. Uzyskano & $90000 \mathrm{~m}^{2}$ powierzchni po modernizacji \\
\hline 3. Stworzono & $95000 \mathrm{~m}^{2}$ nowej powierzchni \\
\hline 4. Odnowiono & $50000 \mathrm{~m}^{2}$ fasad ceglanych \\
\hline 5. Utworzono & $30000 \mathrm{~m}^{2}$ rynku \\
\hline 6. Posadzono & $600 \mathrm{szt}$ drzew \\
\hline 7. Zmodernizowano & $4 \mathrm{~km}$ dróg \\
\hline
\end{tabular}

Źródło: opracowanie własne na podstawie danych ze strony inwestora

Inwestor za jeden z największych sukcesów uznał stworzenie reprezentacyjnego rynku o powierzchni $30000 \mathrm{~m}^{2}$, którego Łódź nie posiadała. Jako symbol inwestycji wybrano 
postać kobiety i mężczyzny zachęcających do wejścia na teren centrum. Na płycie rynku wykorzystano element wzoru z kratki jednego z okien na terenie fabryki Poznańskiego. Posłużył on również w kampanii reklamowej i folderach promocyjnych. Wzdłuż jednego z boków rynku powstała trzystumetrowa „tańcząca fontanna”. Postawiono na nowoczesny disign poprzez włączenie kolorowych elementów do wnętrz kompleksu handlowego i użyteczności publicznej. Na terenie Manufaktury wyznaczono miejsca dla 3500 tys. samochodów. Wnętrza Manufaktury pozwoliły na stworzenie 3000 miejsc pracy, podpisanie umów z 306 najemcami, otwarcie 62 restauracji, pubów, kawiarni, fast-foodów itp., stworzenie Muzeum Fabryki, w której można dowiedzieć się o losach I.K. Poznańskiego, zobaczyć stare zdjęcia, plany fabryki, mapy, a także posłuchać pracy starych maszyn włókienniczych. Dzięki zmianie funkcji z przemysłowej na kulturalno-biznesowo-handlową Manufaktura zyskała nowy wymiar. Wnętrza poprzemysłowego obiektu zaadaptowano na kawiarnie, restauracje, sklepy. W wykańczalni tkanin stworzono 15 sal kinowych, w tym 1 typu IMAX 3D. Powstała arena do jazdy na rolkach, ściana wspinaczkowa, szkoła tańca i platforma do gier wideo.

Tab. 2. Zestawienie powierzchni według przeznaczenia

\begin{tabular}{|l|c|}
\hline \multicolumn{1}{|c|}{ Przeznaczenie } & Powierzchnia \\
\hline 1. Kultura & $8000 \mathrm{~m}^{2}$ \\
\hline 2. Biznes & $20000 \mathrm{~m}^{2}$ \\
\hline 3. Handel & $101000 \mathrm{~m}^{2}$ \\
\hline 4. Rozrywka & $21000 \mathrm{~m}^{2}$ \\
\hline Razem & $150000 \mathrm{~m}^{2}$ \\
\hline
\end{tabular}

Źródło: opracowanie własne na podstawie danych ze strony inwestora

Pod koniec 2008 r. zakończy się remont budynku dawnej przędzalni przy ul. Ogrodowej, przeznaczonego na czterogwiazdkowy hotel Andels. Znajdzie się w nim 160-180 pokoi, 50-70 apartamentów przewidzianych dla rezydentów, sale konferencyjne o powierzchni $1800 \mathrm{~m}^{2}$, sala balowa o powierzchni $800 \mathrm{~m}^{2}$, basen, kluby fitness, puby, a obok parking na 198 samochodów. Inwestor Manufaktury przekazał za „złotówkę” budynek dawnej tkalni na potrzeby Muzeum Sztuki w Łodzi. Do Muzeum zostaną przeniesione zbiory sztuki współczesnej. Powstanie też Centrum Nauki i Techniki dla Dzieci (Eksperymentarium) - pierwsze w Europie Środkowej interaktywne muzeum dla najmłodszych, opracowane wspólnie z Cite des Sciences et de l'Industrie w La Villette w Paryżu. Obecnie część kulturalna Manufaktury obejmuje Muzeum Miejsca, galerie sztuki użytkowej, a także Muzeum Historii Miasta w pałacu Poznańskiego.

\section{WNIOSKI}

Analizując powyższe dane można stwierdzić, iż projekt rewitalizacyjny, chociaż jeszcze niezakończony, okazał się sukcesem. W pierwszym roku Manufakturę odwiedziło ok. $16 \mathrm{mln}$ osób (jest to wynik o $1 \mathrm{mln}$ lepszy niż spodziewał się francuski inwestor). W dniu otwarcia centrum odwiedziło ok. 190 tys. osób. W dni wolne odwiedza Manufakturę 
ok. 70 tys. Rewitalizacja obiektu zmieniła jego funkcje z poprzemysłowej na kulturalno-handlową i miejsca czasu wolnego. Przyczyniła się do wzrostu zatrudnienia, przedsiębiorczości mieszkańców oraz do rewaloryzacji zdegradowanej infrastruktury technicznej i urbanistycznej. Manufaktura coraz częściej kojarzy się z Łodzią, jest jednym z najbardziej charakterystycznych punktów miasta. Ten wynik zawdzięcza nie tylko akcji promocyjnej, prowadzonej na szeroką skalę, ale również charakterowi i klimatowi. Dzięki niemu sprzyja integracji mieszkańców, a tym samym odnosi się do społecznego aspektu rewitalizacji. Inwestor przywrócił obszarowi zdolność funkcjonowania w strukturze miasta. Nowe miejsca pracy zmniejszyły liczbę bezrobotnych. Odnowiono zdegradowaną infrastrukturę obszaru. Stworzono warunki do rozwoju ekonomicznego i społecznego miasta. Ich wynikiem jest wiele pozytywnych zmian, jakie zaszły na odnawianym terenie, ale nie można zapominać o negatywnych efektach. Poniższa analiza przedstawia wady i zalety inwestycji.

Tab. 3. Analiza rewitalizowanego obszaru

\begin{tabular}{|c|c|}
\hline \multicolumn{2}{|c|}{ Analiza rewitalizowanego obszaru } \\
\hline Pozytywne efekty & Negatywne efekty \\
\hline $\begin{array}{l}\text { Nowe miejsca pracy - } 3000 \text { zatrudnionych } \\
\text { pracowników. }\end{array}$ & $\begin{array}{l}\text { Brak mechanizmu spill-over przenoszącego } \\
\text { pozytywne zmiany na obszary przylegające } \\
\text { do Manufaktury. }\end{array}$ \\
\hline $\begin{array}{l}\text { Wzrost atrakcyjności całego miasta, poprzez } \\
\text { pobudzenie ruchu turystycznego - } 15 \mathrm{mln} \\
\text { odwiedzających rocznie. }\end{array}$ & $\begin{array}{l}\text { Brak dobrej infrastruktury - zakorkowane ulice } \\
\text { wokół kompleksu handlowego. }\end{array}$ \\
\hline $\begin{array}{l}\text { Odnowione zespoły fabrycznych budynków } \\
\text { - koszt inwestycji } 120 \text { mln euro zainwestowa- } \\
\text { nych do otwarcia. }\end{array}$ & $\begin{array}{l}\text { Centrum może zaszkodzić ul. Piotrkowskiej, } \\
\text { pełniącej do tej pory funkcję wizytówki miasta, } \\
\text { a także innym centrom handlowym. }\end{array}$ \\
\hline $\begin{array}{l}\text { Zmiana funkcji obiektu poprzemysłowego } \\
\text { na biznesowy, kulturalny, rozrywkowy. }\end{array}$ & $\begin{array}{l}\text { Wyburzenie części historycznych budynków } \\
\text { na potrzeby hipermarketu. }\end{array}$ \\
\hline $\begin{array}{l}\text { Stworzenie miejsca spotkań łodzian - wpływ } \\
\text { na integrację mieszkańców. }\end{array}$ & $\begin{array}{l}\text { Stworzenie zamkniętej przestrzeni } \\
\text { niezintegrowanej z miastem. }\end{array}$ \\
\hline $\begin{array}{l}\text { Stworzenie charakterystycznego dla dużych } \\
\text { miast trzyhektarowego rynku - nie było } \\
\text { takiego miejsca wcześniej w mieście. }\end{array}$ & $\begin{array}{l}\text { Błędy projektowe w pracach konserwatorskich } \\
\text { poprzemysłowych obiektów. }\end{array}$ \\
\hline Umocnienie tożsamości miejsca & $\begin{array}{l}\text { Niewłączenie do rewitalizacji obiektu domów } \\
\text { robotniczych. }\end{array}$ \\
\hline
\end{tabular}

Źródło: opracowanie własne

Jako dobry przykład rewitalizacja obszaru powinna promieniować na obszary przyległe, które nie zostały bezpośrednio włączone w proces odnowy. Jednak teren Manufaktury zamyka się do środka, dysponując niezbędnym zapleczem dla funkcjonowania ,miasta”. Następuje odwrócenie od dotychczasowego „serca” Łodzi, czyli ul. Piotrkowskiej, 
poprzez powstanie rynku. Tworzące główną arterię odchodzące od centrum ulice: Ogrodowa, Gdańska, Zachodnia, pozostają oddzielnym elementem w funkcjonowaniu obszaru. Nie integrują się z nim, tworząc barierę dla tzw. dobrych praktyk związanych z rozwojem obszaru otaczającego Manufakturę. Zarówno tkanka urbanistyczno-architektoniczna, jak również infrastrukturalna, społeczna, ekonomiczna pozostają w fazie stagnacji. Odchodząca od centrum ul. Gdańska nadal pozostaje ulicą o ogromnym potencjale architektonicznym, lecz zaniedbanej infrastrukturze. Mieszkańcy ulicy to często rodziny o zaburzonych relacjach społecznych, z brakiem perspektyw na przyszłość, a mieszczące się przy niej budynki wymagają remontów. Sfera ekonomiczna pozostaje w fazie kryzysu. Niezbędne jest wsparcie w rozwoju architektoniczno-urbanistycznym i stworzenie nowych możliwości rozwoju potencjalnym przedsiębiorcom. Niezbędne jest również kształtowanie związków mieszkańców z miejscem zamieszkania, tak aby możliwe było stworzenie poczucia wartości miejsca, w którym codziennie żyją.

W 2007 r. władze miasta zgodnie z uchwałą nr XXII/464/07 Rady Miejskiej w Łodzi z dnia 5 grudnia 2007 r. w sprawie przyjęcia Programu rewitalizacji domów familijnych przygotowały projekt remontu zabytkowego obszaru, obejmującego m.in. familoki przy ul. Ogrodowej, biegnącej wzdłuż centrum Manufaktura. W ramach projektu mieszkańcy mają otrzymać mieszkania w nowych budynkach na obrzeżach Łodzi. Prace mają potrwać przez okres pięciu lat. W dniach od 15 stycznia do 4 lutego 2007 r. łódzki Magistrat przeprowadził wśród mieszkańców ankietę na temat planowanego procesu rewitalizacji. Badanie miało określić ogólne nastawienie do całego procesu oraz ocenę zainteresowania mieszkańców udziałem w jego realizacji. Jak pokazują wyniki, większość opowiedziała się „za” poprawą warunków. W dawnych mieszkaniach robotniczych mają powstać ekskluzywne apartamenty.

Remont i adaptacja obiektów przyczyniłaby się nie tylko do zmian architektonicznych, ale również do zmiany terenów kryzysowych. Nastąpiłoby otwarcie obszaru, co pozwoliłoby na dalszą rewitalizację.

Podsumowując przedstawione rozważania, należy podkreślić, że rewitalizacja poprzemysłowego obszaru to proces złożony, niosący za sobą wyzwania w postaci nakładów finansowych i pracochłonnych zabiegów technicznych. Rewitalizacji musi towarzyszyć zrównoważony rozwój obszaru, łączący w sobie instrumenty działań ukierunkowane na rozwój społeczny, gospodarczy i ochronę środowiska. Istotne jest, aby zmiana funkcji obszaru dokonywała się w sposób spełniający kryteria degradacji i przenosiła pozytywne efekty na obszary sąsiadujące. Warunkuje to prawidłowy rozwój przestrzenny miasta i wpływa na zagospodarowanie obszarów poprzemysłowych będących w stanie kryzysu. Otwarcie działań rewitalizacyjnych sprzyja przeniesieniu dobrych praktyk, które poprzez tzw. rozlanie łączą tereny i tworzą integralną cześć stymulującą kształtowanie przestrzeni miejskiej.

\section{Literatura}

Czarnecki W., red., 2006, Problemy rewitalizacji w gospodarce przestrzennej XXI wieku, Wyd. Wyższej Szkoły Finansów i Zarządzania, Białystok

Frąckiewicz L., red., 2004, Wykluczenie, rewitalizacja, spójność społeczna, Wyd. „Śląsk”, WN, Katowice-Warszawa

Lorens P., red., 2007, Rewitalizacja miast w Polsce - pierwsze doświadczenia, Warszawa 
Missalowa G., 1977, Studia nad powstaniem łódzkiego okręgu przemysłowego, Wyd. Łódzkie, Łódź Popławska I., 1992, Architektura mieszkaniowa Łodzi w XIX w., Polska Akademia Nauk, Komitet Architektury i Urbanistyki, Warszawa

Szram A., 1998, Inicjatywy budowlane I.K. Poznańskiego jako wyraz mecenatu artystycznego łódzkiego przemystowca, Ośrodek Studiów i Ochrony Środowiska Kulturowego, Łódź

\section{Closed revitalization as an example of post-industrial area management in Lódź}

The purpose of this article is to describe and analyze the notion of closed revitalization as an example of function alteration of post-industrial areas' of I.K. Poznanski factory in Łódź.

In Poland, due to the transformation of the system and economy, the country's entry into the European Community and finally equalization of opportunities and balancing of the differences between our state and the countries of Western Europe, revitalization of degraded urban areas is, currently, more and more often recognized as an important issue. In recent years, several revitalization projects aiming at the alteration of functions of post-industrial areas have been commenced. Non-profitable operation of industrial plants led to a decrease in production and, thus, a decrease in employment. Sizes of the industrial facilities and limited technical possibilities regarding renovation works often did not allow for the development of the facilities by potential lessees. Those locations have stood abandoned and useless for many years, losing their architectural value and contributing to the spatial degradation of their respective city areas. Therefore, the identities of those cities which were strongly associated with industrial production have been gradually lost. Alteration of the functions of such sites by means of revitalization is an opportunity for their prospective development and growth. 